\title{
ANALISIS KEMAMPUAN TEKNIK DASAR PEMAIN SEPAK BOLA SSB DELI SERDANG UNITED KABUPATEN DELI SERDANG
}

\author{
Abdul Harris Handoko \\ Fakultas Ilmu Keolahragaan \\ Universitas Negeri Medan \\ e-mail: abdulharrishandoko@gmail.com
}

\begin{abstract}
In football games not only do the players must have an absolutely great physical condition, but they also must have an excellent technical skill so an amazing game can be played maximally. By looking at that reason, a fundamental technique skill is one of the aspects a football player must have.This research aims to discover how good is the football players' fundamental technique skill. This study was conducted in Deli Serdang United Soccer School's football field in Deli Serdang Regency, and there are 24 players in that soccer school. This study used descriptive qualitative method. This method described and interpreted data related to the current situation, the attitude and point of view which is happening nowadays, the relation between variables, dissimilarity of two or more conditions, its influence towards one particular condition, the differentiation among facts, and other things. Based on the normality test which was done previously with regard to test result with Lilifoers test from entire data attained normal result. Moreover, from the calculation of whole data, score 6,08 point was obtained from passing data and categorized as mediocre, from dribbling obtained 19,6 second and categorized as mediocre as well, and shooting data with 12,6 point was categorized as good. Based on the result of this research and calculated data, and also the discussion which has been done, then from the explanation above it can be concluded that the fundamental technique skill of players in Deli Serdang Soccer School were classified as mediocre and good, where passing and dribbling technique were in mediocre category, while shooting technique was in a good category.
\end{abstract}

Keywords : basic skills, football

\begin{abstract}
ABSTRAK
Dalam pertandingan sepakbola selain pemain memiliki kondisi fisik yang baik, seorang pemain juga sangat dituntut memiliki kemampuan teknik dasar sepakbola yang baik agar terciptanya suatu permainan yang baik dan maksimal. Oleh karena itu kemampuan teknik dasar merupakan suatu unsur yang harus dimiliki oleh seorang pemain sepakbola.

Penelitian ini bertujuan untuk mengetahui seberapa besar kemampuan teknik dasar yang dimiliki oleh pemain sepakbola .Penelitian ini dilakukan di lapangan sepakbola SSB Deli Serdang United Kabupaten Deli Serdang dengan jumlah pemain 24 orang.

Metode penelitian ini menggunakan metode penelitian deskriptif kualitatif. Penelitian deskriptif kualitatif menuturkan dan menafsirkan data yang berkenaan dengan situasi yang terjadi dan dialami sekarang, sikap dan pandangan yang menggejala saat sekarang, hubungan antara variable, pertentangan dua kondisi atau lebih, pengaruh terhadap suatu kondisi, perbedaan antar fakta, dan lain-lain.

Berdasarkan uji normalitas yang dilakukan terhadap hasil tes dengan uji lilifoers dari keseluruhan data memperoleh hasil normal. Dan dari perhitungan pada tiap data, diperoleh pada data passing dengan nilai 6,08 poin dengan kategori sedang, data dribbling dengan nilai
\end{abstract}


19,6 detik dengan kategori sedang, dan data shooting dengan nilai 12,6 poin dengan kategori baik

Berdasarkan hasil penelitian dan perhitungan dari data dan pembahasan yang telah dilakukan, maka dari penjelasan diatas maka dapat diambil kesimpulan bahwa kemampuan teknik dasar sepakbola pemain SSB Deli Serdang United Kabupaten Deli Serdang termasuk dalam kategori sedang dan baik, yang dimana teknik passing dan dribbling dalam kategori sedang, dan teknik shooting dalam kategori baik.

Kata kunci: teknik dasar, sepakbola

\section{PENDAHULUAN}

Olahraga di tanah air masih mem-

butuhkan perhatian dan pembinaan khusus

dalam usaha mencari bibit yang baru mau-

pun usaha meningkatkan prestasi atlet.

Olahraga kini merupakan suatu aktivitas

rutin yang dilakukan oleh masyarakat.

Keberadaannya sekarang ini tidak lagi

dipandang sebelah mata, tetapi sudah men-

jadi bagian dari kegiatan masyarakat.

Olah-raga menjadi salah satu bentuk dari

upaya peningkatan kualitas manusia

Indonesia yang diarahkan pada

pembentukan watak dan kepribadian

maupun disiplin dan sportivitas yang

tinggi serta peningkatan prestasi yang

dapat membangkitkan rasa kebanggaan

nasional (GBHN.Tap MPR No.

11/MPR/1999).
Menurut Cholik Mutohir (1992)

olahraga adalah proses sistematik yang

berupa segala kegiatan atau usaha yang

dapat mendorong mengembangkan, dan

membina potensi-potensi jasmaniah dan

rohaniah seseorang sebagai perorangan

atau anggota masyarakat dalam bentuk

permainan, perlombaan/pertandingan, dan

kegiatan jasmani yang intensif untuk mem-

peroleh rekreasi, kemenangan, dan prestasi

puncak dalam rangka pembentukan manu-

sia Indonesia seutuhnya yang berkualitas

berdasarkan Pancasila. Olahraga juga

dapat dijadikan sebagai alat pemersatu,

mengi-ngat pentingnya peranan olahraga

dalam kehidupan manusia, dalam usaha

ikut serta memajukan manusia Indonesia

yang ber-kualitas, maka pemerintah

Indonesia mengadakan pembinaan dan

pengembang-an di bidang olahraga, seperti 
mengadakan pertandingan-pertandingan

olahraga yang biasanya diikuti oleh semua

kalangan masyarakat.

Peningkatan kemajuan dalam bidang olahraga harus diimbangi dengan peningkatan sumber daya manusia. Dalam hal ini melalui upaya pembinaan serta pengem-bangan olahraga dalam arti luas akan memberikan peranan yang cukup besar untuk menciptakan manusia Indonesia yang berkualitas, karena itu olahraga yang memiliki peranan dalam pembangunan nasional perlu dibina dan dikembangkan.

Salah satu jenis olahraga yang sangat populer dan dikenal masyarakat saat ini adalah sepakbola. Tingginya animo dan minat masyarakat yang bermain sepakbola mulai dari anak-anak hingga orang-orang tua, bahkan perempuan juga ikut berperan menjadikan sepakbola sebagai tren masa kini yang diminati dan digemari berbagai kalangan. Hal itu dapat kita lihat pada setiap lapangan sepakbola yang tidak pernah sepi dan selalu terpakai setiap harinya. Bagi beberapa orang, bermain sepakbola awalnya sekedar hobi, tetapi lama kelamaan menjadi menarik untuk ditekuni secara serius yang bahkan menjadi sarana untuk berprestasi.

Pembinaan sepakbola usia dini menjadi salah satu faktor utama yang mem-pengaruhi prestasi olahraga permainan sepakbola, karena pembinaan di usia dini akan melahirkan pemain-pemain profe-sional yang dibutuhkan dalam pencapaian prestasi yang maksimal. Banyaknya lembaga pendidikan sepakbola (LPSB), dapat dijadikan sebagai lumbung bagi bangsa Indonesia untuk merekrut calon atlet sepakbola yang berkualitas. Di LPSB inilah anak-anak yang memiliki minat di sepakbola dapat belajar berbagai teknik dasar permainan sepakbola, yang menjadi faktor penting yang dibutuhkan dan ber-pengaruh dalam permainan sepakbola. Pe-nguasaan teknik dasar merupakan suatu persyaratan penting yang harus dimiliki oleh setiap pemain agar permainan dapat dilakukan dengan baik. 
Bahkan pemain tersohor asal Belanda Johan Cruyff berkata bahwa, pembentukan pemain sebagian besar terjadi sebelum anak berusia 14 tahun (Timo Scheunemann, 2008:23).

$$
\text { Dalam suatu cabang olahraga }
$$
terdapat beberapa faktor yang berpengaruh pada prestasi seseorang, antara lain: perlu adanya sarana dan prasarana yang diperlukan dalam latihan maupun permainan; harus dapat menguasai teknik dan taktik yang sesuai dengan cabang olahraga yang diminatinya; dan seseorang harus mempunyai mental bertanding yang baik; selain itu yang tak kalah penting harus memiliki kondisi fisik yang baik, karena tanpa kondisi fisik yang baik tidak mungkin seseorang mampu merealisasikan teknik dengan baik. Faktor-faktor tersebut merupakan satu kesatuan yang saling terkait dan tidak dapat dipisahkan, sebagai contoh apa-bila seseorang tidak memiliki taktik dan mental yang baik, maka akan sulit baginya untuk dapat melahirkan prestasi yang mak-simal.
Di antara beberapa cabang olahraga prestasi, sepakbola merupakan olahraga yang banyak dilakukan pembinaan hingga pengembangannya, baik di masyarakat maupun di sekolah. Pembinaan olahraga sepakbola telah dilakukan oleh PSSI yang bekerja sama dengan DIKNAS untuk mengadakan pendidikan dan pelatihan (DIKLAT) sepakbola serta mendirikan sekolah sepakbola (SSB) di beberapa provinsi atau daerah guna menitikberatkan pembi-naan olahraga sepakbola. Diharapkan de-ngan adanya DIKLAT serta SSB ini, nan-tinya Indonesia akan memiliki pemain-pemain yang berpotensi untuk mampu ber-prestasi maksimal baik di tingkat daerah, nasional bahkan internasional. Sehubungan dengan hal itu, kini telah banyak sekolah-sekolah sepakbola yang menampung anak-anak untuk menyalurkan bakat dan minat-nya pada olahraga ini.

Ratusan SSB telah berdiri di Indonesia, yang bertujuan untuk membina anak-anak berusia muda menjadi bibit atlet 
sepakbola yang kelak menjadi pemain kebanggaan bangsa. SSB adalah salah satu bentuk organisasi olahraga sepakbola yang berfungsi untuk memberikan dasar-dasar bermain serta mengembangkan potensi seorang siswa atau atlet dalam permainan sepakbola, sehingga SSB menjadi wadah pembinaan sepakbola usia dini yang paling tepat, bahkan saat ini beberapa SSB memiliki siswa yang banyak. Hal ini merupakan fenomena yang baik, mengingat SSB sebagai akar pembinaan prestasi sepakbola nasional yang mampu menjadi penyuplai pemain yang berkualitas.

Dalam upaya untuk mencapai suatu prestasi dalam permainan sepakbola, ada beberapa komponen dan faktor yang menunjang, salah satunya kemampuan teknik dasar sepakbola. Teknik dasar adalah semua kegiatan yang mendasar pada permainan, yang dalam permainan sepakbola menjadi modal maupun pondasi bagi seseorang untuk dapat bermain sepakbola. Ada-pun teknik-teknik dasar dalam olahraga se-pakbola antara lain: passing, shooting, dan dribbling.

Perkembangan sepakbola di Provin-si Sumatera Utara cukup mendapat perha-tian dari pemerintah, terbukti dengan dise-lenggarakannya kegiatan Pekan Olahraga Pelajar Daerah (POPDA) bagi pelajar untuk tingkat SMP, SMA sederajat yang di da-lamnya turut mempertandingkan olahraga sepakbola. Selain itu, pada tingkat SSB ju-ga sering diadakan turnamen antar klub un-tuk kategori U-13, U-15 dan U-17 oleh berbagai daerah maupun turnamen resmi lainnya. Diharapkan dari beberapa ajang ini, nantinya akan muncul bibit-bibit pemain sepakbola baru yang berpotensi serta berkualitas.

SSB Deli Serdang United Kabupaten Deli Serdang merupakan satu dari bebe-rapa SSB di Indonesia yang dapat menjadi wadah untuk menyalurkan hobi dan bakat dalam bermain sepakbola untuk pemain usia dini. Diharapkan anggota SSB ini me-miliki kemampuan teknik dasar 
yang ter-latih dan dapat menjadi pemain yang ber-prestasi di tingkat kabupaten, provinsi, na-sional, maupun internasional sehingga da-pat mengharumkan nama bangsa dan ne-gara. SSB Deli Serdang United Kabupaten Deli Serdang didirikan pada 8 Agustus 2015, yang berlokasi di Lubuk Pakam, Ka-bupaten Deli Serdang.

Dari uraian yang telah dijabarkan sebelumnya, mengingat di dalam sepakbola suatu kemampuan teknik dasar sangat ber-kaitan dengan prestasi seorang atlet, maka peneliti tertarik untuk mengukur unsur ter-sebut, yaitu: "Kemampuan teknik dasar pe-main sepakbola SSB Deli Serdang United Kabupaten Deli Serdang”.

\section{Identifikasi Masalah}

1. Belum diketahui seberapa besar kemam-puan teknik dasar pemain sepakbola SSB Deli Serdang United Kabupaten Deli Serdang.

2. Belum diketahuinya teknik dasar sepakbola mana yang paling sangat kurang, dan perlu diberikan latihan khusus.

\section{Batasan Masalah}

Supaya adanya persepsi yang sama dalam menelaah penelitian ini, maka perlunya diadakan pembatasan masalah. Adapun masalah yang harus dibatasi adalah: Kemampuan teknik dasar pemain sepakbola SSB Deli Serdang United Kabupaten Deli Serdang, yaitu: teknik shooting, dribbling, dan passing.

\section{Definisi Operasional}

Untuk tidak terjadinya salah pengertian mengenai istilah-istilah, maka perlu penjelasan istilah-istilah dalam penelitian sebagai berikut:

1. Analisis adalah suatu kegiatan untuk melihat, menilai, dan menyimpulkan suatu penelitian yang dilakukan kepada suatu objek untuk mengetahui seberapa besar kemampuan yang dimiliki oleh orang tersebut.

2. Kemampuan adalah kecakapan atau potensi seorang individu untuk menguasai keahlian yang dilatih untuk memperoleh hasil yang maksimal. Kemampuan gerak diperoleh melalui proses belajar 
yaitu dengan cara memahami serta mela-kukan gerakan berulang-ulang secara sa-dar akan ketepatan dari gerakan yang telah dilakukan.

3. Teknik dasar adalah kemampuan pemain untuk melakukan gerakan-gerakan dari permainan sepakbola, berupa teknik passing, dribbling, shooting.

Rumusan Masalah

Sesuai dengan judul dalam peneliti-an ini, adapun rumusan masalahnya adalah sebagai berikut: "Analisis kemampuan tek-nik dasar pemain sepakbola SSB Deli Serdang United Kabupaten Deli Serdang”.

\section{Tujuan Penelitian}

Berdasarkan masalah penelitian di atas maka tujuan dari penelitian ini adalah: Untuk mengetahui kemampuan teknik dasar pemain sepakbola SSB Deli Serdang United Kabupaten Deli Serdang.

\section{Manfaat Penelitian}

Adapun manfaat dari penelitian ini adalah sebagai berikut:
1. Pelatih dan pemain dapat memahami bahwa kemampuan teknik dasar sangat mempengaruhi capaian prestasi dalam olahraga sepakbola.

2. Peneliti ini akan memberikan kontribusi yang baik pada sekolah dan klub-klub sepakbola bagaimana melihat kemampuan teknik dasar sepakbola.

3. Dengan dilaksanakan penelitian ini diharapkan akan memicu motivasi para pemain untuk menekuni olahraga sepak-bola.

\section{METODOLOGI PENELITIAN}

Tempat dan Waktu Penelitian

Penelitian ini akan dilaksanakan di lapangan sepakbola SSB Deli Serdang United Kabupaten Deli Serdang dan dilaku-kan mulai dari bulan Juli s/d September 2017 sesuai dari jadwal yang diberikan oleh pihak Fakultas Ilmu Keolahragaan.

\section{Rancangan Penelitian}

Metode penelitian ini menggunakan metode penelitian deskriptif 
kualitatif, yaitu penelitian yang ingin mengetahui se-berapa besar kemampuan yang dimiliki oleh setiap pemain yang dapat dinilai mela-lui angka atau numerik sehingga dapat di-kualifikasikan ke dalam beberapa kategori: baik, sedang atau kurang. Penelitian ini di-maksudkan untuk mengangkat fakta, kea-daan, variabel, dan fenomena-fenomena yang terjadi saat sekarang (ketika penelitian berlangsung) dan menyajikan apa adanya.

\section{Populasi dan Sampel}

Populasi adalah seluruh individu yang ditetapkan menjadi sumber data atau subjek penelitian, (Arikunto 2010: 130). Populasi dalam penelitian ini berjumlah 110 orang, yang rinciannya dapat dilihat pada tabel 1 .

Tabel 1. Populasi Penelitian

\begin{tabular}{|c|c|c|}
\hline No & $\begin{array}{c}\text { Kelompok } \\
\text { Usia }\end{array}$ & Jumlah \\
\hline 1 & 19- 21 & 32 Orang \\
\hline 2 & $16-18$ & 25 Orang \\
\hline 3 & $13-15$ & 24 Orang \\
\hline 4 & $10-12$ & 29 Orang \\
\hline \multicolumn{2}{|r|}{ Jumlah } & 110 Orang \\
\hline
\end{tabular}

Sampel adalah sebagian atau wakil dari populasi yang diteliti. Mengenai besarnya sampel yang cukup untuk populasi, Arikunto (2010: 134) mengatakan bahwa: apabila subjeknya kurang dari 100, lebih baik diambil semua sehingga penelitiannya merupakan penelitian populasi. Selanjutnya jika subjeknya besar dapat diambil antara $10-20 \%$ atau $20-25 \%$ atau lebih. Maka sampel yang digunakan dalam penelitian ini adalah pemain sepakbola SSB Deli Serdang United Kabupaten Deli Serdang usia 13 s/d 15 tahun yang berjumlah 24 orang.

\section{Variabel Penelitian}

Variabel adalah gejala yang bervariasi yang menjadi objek penelitian atau apa yang menjadi titik perhatian suatu pene-litian (Arikunto, 2010: 116). Adapun varia-bel bebas penelitian ini adalah kemampuan teknik dasar sepakbola. Dan variabel terikat adalah variabel yang dipengaruhi. Variabel terikat dalam penelitian ini adalah pemain sepakbola SSB Deli Serdang United Kabu-paten Deli Serdang usia 13 s/d 15 tahun. 


\section{Instrumen Penelitian}

Untuk memperoleh data dalam penelitian ini dilakukan tes pada pemain sepakbola SSB Deli Serdang United Kabupaten Deli Serdang usia 13 s/d 15 Tahun de-ngan jumlah 24 orang, yang menjadi sam-pel sesuai dengan dengan kebutuhan pene-litian. Bentuk tes yang dilakukan dalam pe-nelitian ini adalah tes kemampuan teknik dasar sepakbola (passing, dribbling dan shooting). Adapun alat-alat yang digu-nakan dalam pelaksanaan penelitian ini adalah buku catatan, stop watch, peluit, bola, kapur, dan 6 buah rintangan (tongkat atau tiang).

\section{Teknik Pengumpulan Data}

Dalam penelitian ini data merupakan faktor yang penting, karena dengan adanya analisis data dapat dilakukan dan selanjutnya dapat ditarik simpulan. Data penelitian dihimpun langsung melalui tes kemampuan teknik dasar, antara lain:

\section{Passing}

Petunjuk pelaksanaan: a. Testee berdiri di belakang garis yang berjarak 9 meter dari sasaran, dengan posisi kaki kanan atau kiri siap menembak sesuai dengan kebi-asaan testee.

b. Aba-aba "ya", testee mulai menendang bola kesasaran sebanyak 10 kali.

c. Tendangan dianggap sah dan dihitung masuk apabila masuk pada bidang sasaran, mengenai batas atas dan atau mengenai pancang, dan kerasnya tendangan harus sampai pada garis batas dari arah bersebe-rangan (jarak 9 meter). Penilaian-nya adalah jumlah tendangan yang masuk sah dari sepuluh kali ten-dangan.

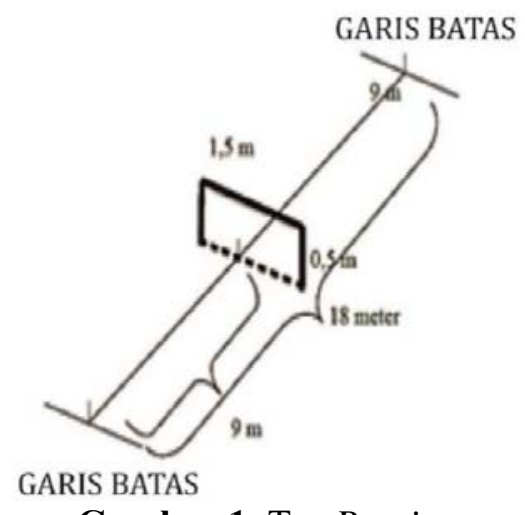

Gambar 1. Tes Passing (Sumber: Subagyo, 1995: 34) 
Tabel 2. Norma tes Passing

\begin{tabular}{|c|c|l|}
\hline No & $\begin{array}{c}\text { Jumlah } \\
\text { Nilai }\end{array}$ & \multicolumn{1}{|c|}{ Kriteria } \\
\hline 1 & $9-10$ & Baik sekali \\
\hline 2 & $7-8$ & Baik \\
\hline 3 & $5-6$ & Sedang \\
\hline 4 & $3-4$ & Kurang \\
\hline 5 & $0-2$ & Kurang sekali \\
\hline
\end{tabular}

(Sumber: Subagyo, 1995: 34)

\section{Dribbling}

Petunjuk pelaksanaan:

a. Pada aba-aba "siap", testee berdiri di belakang garis start dengan bola dalam penguasaan kakinya. Pada aba-aba "ya", testee mulai menggiring bola melewati rintangan pertama dan berikutnya, menuju rintang-an berikutnya sesuai dengan arah panah yang telah ditetapkan sampai ia melewati garis finish.

b. Bila salah arah, ia harus memperba-ikinya dengan waktu tetap berjalan

c. Bola digiring oleh kaki kanan dan kiri secara bergantian, atau paling tidak salah satu kaki pernah me- nyentuh bola. (Nurhasan,

2001:160)

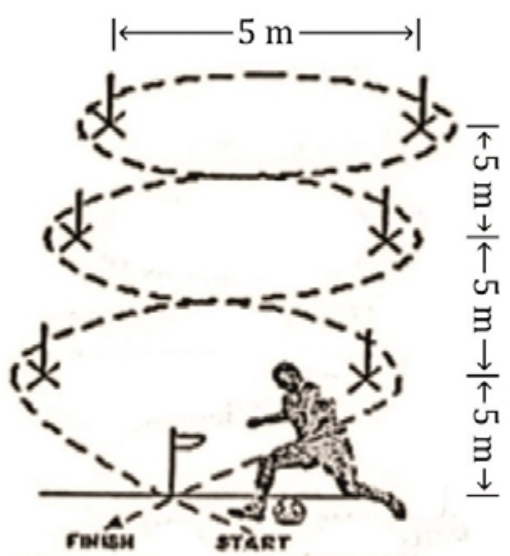

Gambar 2. Tes Menggiring Bola

(Sumber: Nurhasan, 2001:161)

Tabel 3. Tes menggiring bola

\begin{tabular}{|c|c|l|}
\hline $\begin{array}{c}\text { Jarak } \\
\text { (meter) }\end{array}$ & $\begin{array}{c}\text { Waktu } \\
\text { (detik) }\end{array}$ & \multicolumn{1}{|c|}{ Kategori } \\
\hline \multirow{5}{*}{} & $<17,01$ & Sangat baik \\
\cline { 2 - 3 } & $17,01-19,00$ & Baik \\
\cline { 2 - 3 } & $19,01-21,00$ & Sedang \\
\cline { 2 - 3 } & $21,01-23,00$ & Kurang \\
\cline { 2 - 3 } & $>23,00$ & Sangat kurang \\
\hline
\end{tabular}

Sumber:

http://www.tesdanpengukuran.com./ (diakses pada tanggal 21 Agustus 2016)

Tabel 4. Tes Shooting

\begin{tabular}{|c|c|l|}
\hline $\begin{array}{c}\text { Jarak } \\
\text { (meter) }\end{array}$ & Poin & \multicolumn{1}{|c|}{ Kategori } \\
\hline \multirow{6}{*}{} & $\geq 17$ & Sangat baik \\
\cline { 2 - 3 } & $12-16$ & Baik \\
\cline { 2 - 3 } & $8-11$ & Sedang \\
\cline { 2 - 3 } & $4-7$ & Kurang \\
\cline { 2 - 3 } & $\leq 3$ & Sangat kurang \\
\hline
\end{tabular}

Sumber:

http://www.tesdanpengukuran.com./ (diakses pada tanggal 21 Agustus 2016)

\section{Shooting}

Petunjuk pelaksanaan: 
a. Testee berdiri di belakang bola yang diletakkan pada sebuah titik yang berjarak $16,5 \mathrm{~m}$ di depan gawang. Testee diberi 3 (tiga) kali melaku-kan tendangan ke arah sasaran. Serta memiliki 3 kali kesempatan. b. Skor tertinggi dari 3 kali kesempatan dijadikan data penelitian.

c. Bila bola hasil tendangan bola mengenai tali atau garis pemisah skor pada sasaran, maka diambil skor terbesar dari kedua sasaran tersebut.

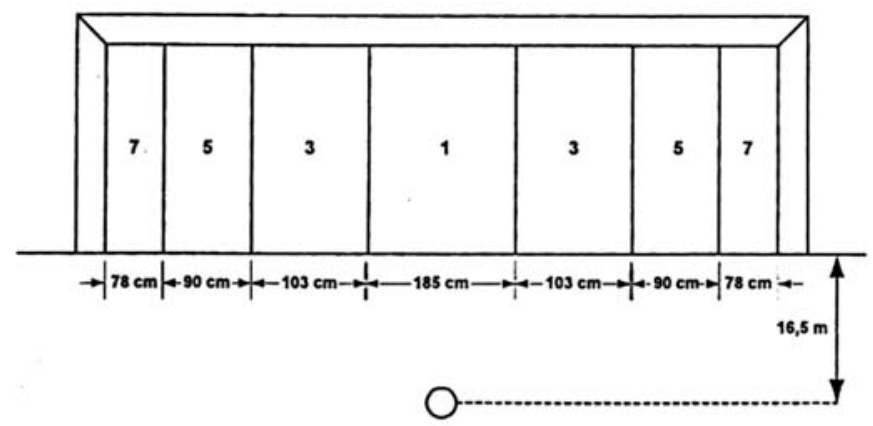

Gambar 3. Tes Menembak Bola ke Sasaran (Shooting) Sumber: Nurhasan (2001:163)

Teknik Analisis Data

Menurut Anas Sudijono (2012:

40), frekuensi relatif atau tabel persentase dika-takan "frekuensi relatif" sebab frekuensi yang disajikan di sini bukanlah frekuensi yang sebenarnya,melainkan frekuensi yang dituangkan dalam bentuk angka persenan, sehingga untuk menghitung persentase res-ponden digunakan rumus sebagai berikut:

Tabel 5. Frekuensi tes Passing

\begin{tabular}{|c|c|c|r|l|}
\hline \multirow{2}{*}{ No } & \multirow{2}{*}{$\begin{array}{c}\text { Kelas Interval } \\
\text { Passing }\end{array}$} & \multicolumn{2}{|c|}{ Frekuensi } & \multirow{2}{*}{ Klasifikasi } \\
\cline { 3 - 4 } & $9-10$ & 1 & \multicolumn{1}{|c|}{ P } & \\
\hline 1 & $7-8$ & 8 & 3,17 & Baik sekali \\
\hline 2 & & & & \\
\hline
\end{tabular}

Keterangan:

$\mathrm{F}=$ Frekuensi yang sedang dicari persentasenya $\mathrm{N}=$ Number of Cases (jumlah frekuensi/ banyaknya individu)

$\mathrm{P}=$ angka persentase 


\begin{tabular}{|l|c|c|r|l|}
\hline 3 & $5-6$ & 12 & 50,00 & Sedang \\
\hline 4 & $3-4$ & 3 & 12,50 & Kurang \\
\hline 5 & $0-2$ & 0 & 0,00 & Sangat kurang \\
\hline \multicolumn{2}{|c|}{ Jumlah } & 24 & 100,00 & \\
\hline
\end{tabular}

HASIL PENELITIAN DAN

PEMBAHASAN

Deskripsi Data Penelitian

Berdasarkan dari data yang telah di-kumpulkan sebelumnya, maka di dalam bab ini akan dilakukan analisis pembahasan yang diperoleh dalam penelitian ini. Hasil penelitian ini akan digambarkan sesuai dengan tujuan dan hipotesis yang diajukan sebelumnya.

\section{Hasil Kemampuan Teknik Dasar} Sepakbola SSB Deli Serdang United

a. Tes Passing

Berdasarkan tabel 5, hasil penelitian tes passing dari 24 orang pemain SSB Deli Serdang United Kabupaten Deli Serdang, diketahui bahwa 1 orang $(4,17 \%)$ dalam kate-gori baik sekali, 8 orang $(33,33 \%)$ dalam kategori baik, 12 orang $(50,00 \%)$ dalam kategori sedang, dan 3 orang $(12,50 \%)$ dalam kate-gori kurang.

Jika dilihat dari hasil tes rata-rata kemampuan teknik dasar sepakbola Pemain SSB Deli Serdang United Kabupaten Deli Serdang dapat dilihat dari hasil data penelitian pada tes passing dari rata-rata perhitungan diperoleh de-ngan 6,08 poin dari 24 orang dan termasuk dalam kategori sedang.

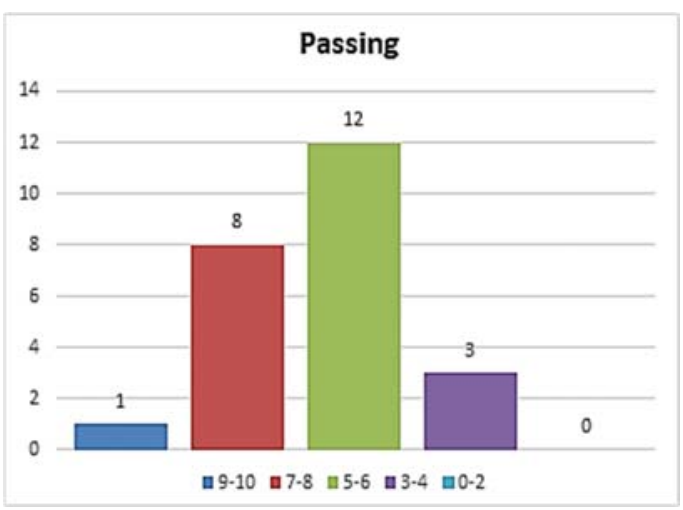

Gambar 4. Grafik tes Passing

Tabel 6. Frekuensi tes Dribbling 


\begin{tabular}{|c|c|c|r|l|}
\hline \multirow{2}{*}{ No } & \multirow{2}{*}{$\begin{array}{c}\text { Kelas Interval } \\
\text { Dribbling }\end{array}$} & \multicolumn{2}{|c|}{ Frekuensi } & \multirow{2}{*}{ Klasifikasi } \\
\cline { 3 - 4 } & $\leq 17,00$ & 0 & \multicolumn{1}{c|}{ P } & \\
\hline 1 & $17,01-19,00$ & 5 & 20,00 & Baik sekali \\
\hline 2 & $19,01-21,00$ & 19 & 79,17 & Baik \\
\hline 3 & $21,01-23,00$ & 0 & 0,00 & Kung \\
\hline 4 & $\geq 23,01$ & 0 & 0,00 & Sangat kurang \\
\hline 5 & Jumlah & 24 & 100,00 & \\
\hline \multicolumn{3}{|c|}{} \\
\hline
\end{tabular}

Tabel 7. Frekuensi tes Shooting

\begin{tabular}{|c|c|c|r|l|}
\hline \multirow{2}{*}{ No } & \multirow{2}{*}{$\begin{array}{c}\text { Kelas Interval } \\
\text { Shooting }\end{array}$} & \multicolumn{2}{|c|}{ Frekuensi } & \multirow{2}{*}{ Klasifikasi } \\
\cline { 3 - 4 } & $\geq 17$ & 2 & \multicolumn{1}{c|}{$\mathbf{P}$} & \\
\hline 1 & $12-16$ & 14 & 8,33 & Baik sekali \\
\hline 2 & $8-11$ & 7 & 29,17 & Sedang \\
\hline 3 & $4-7$ & 1 & 4,17 & Kurang \\
\hline 4 & $\leq 3$ & 0 & 0,00 & Sangat kurang \\
\hline 5 & Jumlah & 24 & 100,00 & \\
\hline \multicolumn{3}{|c|}{} \\
\hline
\end{tabular}

b. Tes Dribbling

Berdasarkan tabel 6 , hasil penelitian tes dribbling dari 24 orang pemain SSB Deli Serdang United Kabupaten Deli Serdang, diketahui 5 orang $(20,83 \%)$ dalam kategori baik, 19 orang $(79,17 \%)$ kategori sedang.

Jika dilihat dari hasil tes rata-rata kemampuan teknik dasar pada hasil tes dribbling dari ratarata perhitungan diperoleh 19,6 detik dari 24 orang dan termasuk dalam kategori sedang.

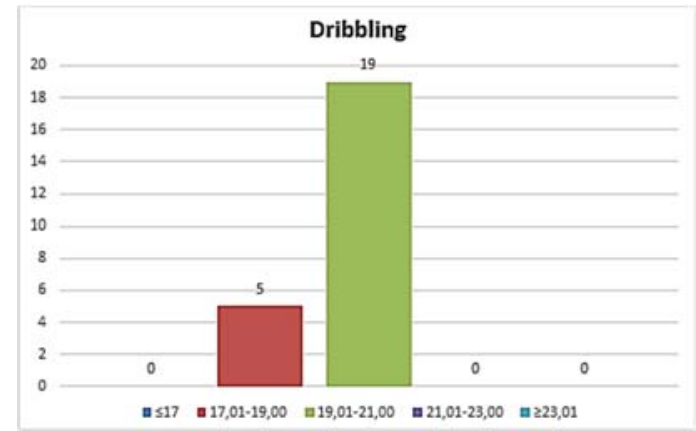

Gambar 5. Grafik tes Dribbling

c. Tes Shooting

Berdasarkan tabel 7, hasil penelitian tes shooting dari 24 orang pemain SSB Deli Serdang United Kabupaten Deli Serdang, diketahui 2 orang $(8,33 \%)$ dalam kategori baik sekali, 14 orang $(58,33 \%)$ kate-gori baik, 7 orang 
(29,17\%) kate-gori sedang, dan 1

orang $(4,17 \%)$ masuk dalam

kategori kurang.

Jika dilihat dari hasil tes rata-rata kemampuan teknik dasar pada tes shooting dari rata-rata perhitungan diperoleh 12,6 poin dari 24 orang dan termasuk dalam kategori baik.

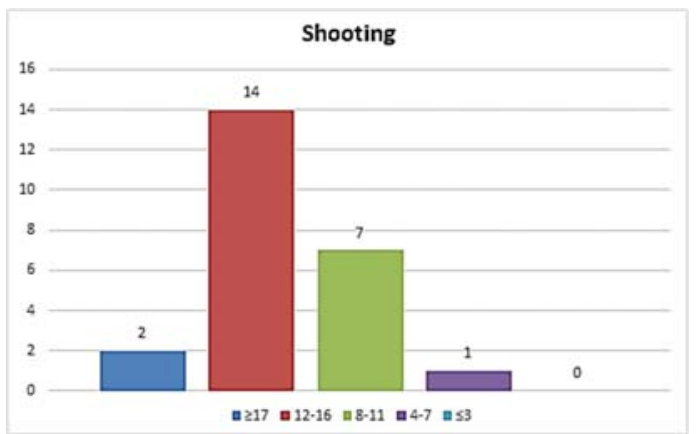

Gambar 6. Grafik tes Shooting

Pembahasan

Penelitian ini termasuk dalam kategori penelitian Deskriptif Kualitatif, merupakan penelitian yang bertujuan untuk mengetahui seberapa besar teknik dasar sepakbola pemain SSB Deli Serdang United Kabupaten Deli Serdang. Akibat yang ada dalam penelitian ini dapat dilihat adanya hasil yang diperoleh dari pemain SSB Deli Serdang United Kabupaten Deli Serdang.
Di dalam olahraga sepakbola suatu prestasi tidak dapat diperoleh dari suatu kondisi fisik dan kerja sama tim saja, namun juga harus didukung oleh kemampuan teknik dasar yang dimiliki oleh setiap pemain. Dalam permainan sepakbola ada beberapa kemampuan teknik dasar sepakbola yang sangat penting untuk dikuasai ialah passsing, dribbling dan shooting, karena ketiga teknik tersebut merupakan faktor utama agar suatu tim dapat bermain dengan baik dan menghasilkan kemenangan.

Dari hasil tes kemampuan teknik dasar sepakbola pemain SSB Deli Serdang United Kabupaten Deli Serdang, hasil data penelitian pada tes passing dari rata-rata perhitungan diperoleh dengan 6,08 poin ter-masuk dalam kategori sedang. Adapun ke-mampuan passing pemain SSB Deli Serdang United Kabupaten Deli Serdang masuk dalam kategori sedang dikarenakan ada 3 pemain yang memperoleh kategori kurang serta 12 orang dalam kategori sedang, 8 orang dalam kategori baik, dan 1 
orang memperoleh kategori baik sekali, dari keseluruhan pemain dirata-ratakan memperoleh kategori sedang.

Dan pada tes dribbling dari ratarata perhitungan diperoleh dengan 19,6 detik dan termasuk dalam kategori sedang. Ada-pun kemampuan dribbling pemain SSB Deli Serdang United Kabupaten Deli Serdang masuk dalam kategori sedang dikarenakan ada 19 pemain yang memperoleh kategori sedang, dan 5 orang memper-oleh kategori baik, dari keseluruhan pemain yang berjumlah 24 maka dirata-ratakan memperoleh kategori sedang.

Serta pada tes shooting dari ratarata perhitungan diperoleh dengan 22,6 poin dan termasuk dalam kategori baik. Adapun kemampuan shooting pemain SSB

Deli Serdang United Kabupaten Deli Serdang masuk dalam kategori baik dikarenakan ada 1 pemain yang memperoleh kategori kurang serta 7 orang dalam kategori sedang, 14 orang dalam kategori baik, dan 2 orang memperoleh kategori baik sekali, dari keseluruhan pemain yang berjumlah 24 maka dirata-ratakan memper-oleh kategori baik.

Melihat dari hasil data yang diperoleh maka dapat disimpulkan bahwa pemain SSB Deli Serdang United Kabupaten Deli Serdang memiliki kemampuan teknik dasar sepakbola dapat dikatakan dalam skala atau kategori sedang, karena teknik dasar pemain tidak memperoleh kategori kurang dan bahkan ada yang memperoleh kategori baik pada teknik shooting.

Dari hasil data penelitian dan prestasi yang diterima oleh pemain SSB Deli Serdang United Kabupaten Deli Serdang semua itu tidak terlepas dari kondisi lapangan yang ada tersebut. Adapun kondisi lapangan SSB Deli Serdang United Kabupaten Deli Serdang bisa dikatakan bagus dan layak untuk digunakan dalam permainan sepakbola, lapangan sepakbola di SSB Deli Serdang United Kabupaten Deli Serdang ada 1 lapangan yang terletak di Lubuk Pakam. Dari hasil penelitian ini diharapkan pelatih membuat program latihan 
yang mengkhususkan untuk meningkatkan teknik dasar sepakbola seperti shooting, passing, dan dribbling, sehingga kemampuan teknik dasar pemain dapat meningkat dan memperoleh kategori baik,

Secara teori hasil penelitian ini memberikan masukan bahwa prestasi merupakan capaian akhir yang dicapai oleh setiap pemain yang berupa Juara dalam suatu Turnamen atau pertandingan. Namun kita harus tahu bahwa kemampuan teknik dasar sepakbola yang baik dapat mempeng-aruhi prestasi yang diperoleh atau yang di-hasilkan selama ini. Tanpa adanya kemam-puan teknik dasar yang baik maka kecil ke-mungkinan suatu prestasi yang tinggi akan dicapai.

\section{PENUTUP}

\section{Kesimpulan}

Berdasarkan data yang diperoleh, diketahui bahwa pemain SSB Deli Serdang United Kabupaten Deli Serdang memiliki kemampuan teknik dasar sepakbola sebagai berikut: teknik passing termasuk dalam kategori sedang, teknik dribbling termasuk dalam kategori sedang, dan teknik shooting termasuk dalam kategori baik.

\section{Saran}

1. Diharapkan pelatih memberikan program latihan yang dapat meningkatkan kemampuan teknik dasar sepakbola pemain Junior SSB Deli Serdang United Kabupaten Deli Serdang.

2. Untuk meneliti menggunakan alat yang lain untuk melihat kemampuan teknik dasar sepakbola pemain Junior SSB Deli Serdang United Kabupaten Deli Serdang.

\section{DAFTAR PUSTAKA}

Arikunto, Suharsimi. (2010). Prosedur Penelitian Suatu Pendekatan Praktik. Jakarta: PT. Rineka Cipta.

Batty, E. C. (2005). Latihan Sepak Bola Metode Baru. Bandung: Pionir Jaya.

Darmawan, Rahmad. (2012). Jadi Juara Dengan Sepakbola Possesion. Jakarta: Ganesha Putra.

Fatah, Muhammad A.N. (2014). "Survei Tentang Kondisi Fisik Dan Kemampuan Teknik Dasar Pada SSB Se-Kecamatan Jepara 
Kabupaten Jepara”. ISSN 22526773

GBHN.Tap MPR No. 11/MPR/1999

Kiram, Yanuar. (1992). Belajar Motorik. Jakarta: Dirjendikti.

Laksono, Wahyu Tri. (2015). "Mengetahui tingkat keterampilandasar sepakbola siswa peserta ekstrakurikuler sepakbola di SMP Negeri 4 Sentolo, Kabupaten Kulonprogo".

Luxbacher, Joseph A. (1998). Sepakbola. Jakarta: PT Raja Grafindo Persada

Mielke, Danny. (2007). Dasar-dasar Sepak Bola. Bandung: Pakar Raya.

Mochtar, Remmy. (1992). Olahraga Pilihan Sepak Bola. Jakarta: Dirjendikti Proyek Pembinaan Tenaga.

Mutohir, Cholik. (1992). UU Sistem Keolahragaan Nasional. Penerbit: Sunda Kelapa Pustaka.

Nurhasan, (2001). Tes dan Pengukuran dalam Pendidikan Jasmani: Prinsip-Prinsip dan Penerapannya. Jakarta: Direktorat Jenderal Olahraga, Depdiknas.

Indarto, Pungki. (2010). “Analisis Kondisi Fisik Dan Keterampilan Gerak Dasar Sepak Bola Anak Usia 12-14 Tahun Pada Sekolah Sepakbola SeKota Surakarta Tahun 2009”.
Rahmani, Mikanda. (2014). Buku Super Lengkap Olahraga. Jakarta: Dunia Cerdas.

Roji dan Eva. (2014). Pendidikan Jasmani Olahraga dan Kesehatan. Jakarta: Kementerian Pendidikan dan Kebudayaan.

Sasmita, Ganjar Purnama. (2010). Skripsi. "Tinjauan Kondisi Fisik Pemain Sekolah Sepakbola (SSB) Generasi Muda Ganting (GMG) Kelompok Umur-15 Kota Padang Panjang"

Scheunemann, Timo. (2005). Kinesiology. Malang: Dioma

Sugiyanto dan Sudjarwo. (1991). Perkembangan dan Belajar Gerak. Jakarta: Depdikbud.

Sukamti, Endang Rini, dkk. (2007). Diktat Perkembangan Motorik. Yogyakarta: FIK UNY.

Sukatamsi. (1985). Teknik Dasar Bermain Sepak Bola. Surakarta: Tiga Serangkai.

Sucipto, dkk. (2000). Sepak Bola. Jakarta: Departemen Pendidikan dan Kebudayaan.

Tenang. (2008). Mahir bermain futsal. Bandung: Ganeca Exact.

Wisahati, A. N dan Santosa, T. (2010). Pendidikan Jasmani Olahraga dan Kesehatan. Jakarta: CV. Setiaji. 